\title{
A literature review of eutrophication in Life Cycle Assessment. Relevance for pampean agroecosystems in Argentina
}

DOI: $10.46932 / \mathrm{sfjdv} 3 \mathrm{n} 1-046$

Received in: Dec 30st, 2021

Accepted in: Jan 1th, 2022

\section{Eliana Conci}

Licenciada en Ambiente y Energías Renovables. Becaria Interna Doctoral de CONICET. Grupo CLIOPE (Universidad Tecnológica Nacional-Facultad Regional Mendoza). Cnel. Rodríguez 273, Mendoza, Argentina.

Consejo Nacional de Investigaciones Científicas y Técnicas (CONICET)-CCT Mendoza. Mendoza, Argentina.

E-mail: econci@mendoza-conicet.gob.ar

\section{Analía Rosa Becker}

Licenciada en Geología. Doctora en Ciencias Geológicas. Posdoctorado en Ciencias Ambientales. I. A. P. de Cs. Básicas y Aplicadas, Universidad Nacional de Villa María. Av. A. Jauretche 1555, Villa María, Córdoba, Argentina.

Instituto Multidisciplinario de Investigación y Transferencia Agroalimentaria y Biotecnológica (IMITAB), CONICET-UNVM. Villa María, Córdoba, Argentina.

Universidad Nacional de Río Cuarto. Ruta Nacional 36, km 601, Río Cuarto, Córdoba, Argentina. E-mail: abecker@exa.unrc.edu.ar

\section{Alejandro Pablo Arena}

Ingeniero Electromecánico. Doctor en Energética. Beca Posdoctoral en Tecnologías para la habitabilidad higrotérmica del sector edilicio en zonas andinas-sustentabilidad energética, impacto ambiental y factibilidad económica.

Grupo CLIOPE (Universidad Tecnológica Nacional-Facultad Regional Mendoza). Cnel. Rodríguez 273, Mendoza, Argentina.

Consejo Nacional de Investigaciones Científicas y Técnicas (CONICET)-CCT Mendoza. Mendoza, Argentina.

E-mail: aparena@gmail.com

\section{Bárbara María Civit}

Ingeniera Química. Doctora en Ingeniería. Posdoctorado en Análisis de Ciclo de Vida, Evaluación de Impactos, producción y consumo responsable.

Grupo CLIOPE (Universidad Tecnológica Nacional-Facultad Regional Mendoza). Cnel. Rodríguez 273, Mendoza, Argentina.

Consejo Nacional de Investigaciones Científicas y Técnicas (CONICET)-CCT Mendoza. Mendoza, Argentina.

E-mail: barbara.civit@gmail.com

\footnotetext{
ABSTRACT

The tools that operate within the framework of life cycle thinking have acquired great relevance, since they make it possible to determine the environmental profile of the system being evaluated. One of the risks deriving from the various economic activities is the eutrophication of water bodies and soil, and these categories are considered in all Life Cycle Impact Assessment (LCIA) models. However, aquatic
} 
and terrestrial eutrophication is not yet exhaustively explored in the field of Life Cycle Assessment (LCA) in Argentina.

A systematic analysis of specific national and international antecedents on these impact categories is carried out, focusing on terrestrial ecosystems, given the productive matrix and the advance of the agricultural frontier in the region. In the absence of research articles, it is deduced that there are no sitedependent characterizing factors (CFs) to evaluate environmental impacts in environmentally significant areas, given that there are no antecedents on the integrated analysis of aquatic and terrestrial ecosystems. The methods and their models will be selected based on the one that best suits regional conditions, following the guidelines agreed upon at the Pellston Workshop 2018. This research can be further developed, continuing with the characterization of the ecosystems receiving the emissions. Argentina is currently considered one of the major agricultural regions of the world, with most activity centered in the Pampa region. The development of regional indicators for this region within the LCIA stage is of great relevance, since it will allow the quantification of environmental impacts derived from activities of great economic importance for the country, positioning itself as an advance in the study of environmental risks in the region.

Keywords nutrients, soils, Life Cycle Impact Assessment, regionalization, midpoint, indicators.

\section{INTRODUCTION}

A production system obeys to multiple interactions between the use of natural resources and the applied technology, so it is necessary to understand the degree of fragility of the systems to avoid reaching extremes of deterioration (Fernández and Urricariet 2014).

The growing awareness of the importance of environmental protection and the potential impacts associated with products has increased interest in the development of methods to understand and address these impacts. One of the techniques developed in this sense is Life Cycle Analysis (ISO 2006a), which was born in the 1960s, when it became evident that the only effective way to analyze industrial systems was to examine all the processes followed by the raw material (Arena 1999). However, it is in the 1990s when the consolidation of this methodology took place (Schmid 2008). This environmental assessment tool is widely used in the world's most industrialized countries. However, in developing countries it has spread with some delay due to methodological difficulties, high implementation costs, lack of motivation, etc. (Arena 1999). In this regard, the UN (2018) has established as a target of Sustainable Development Goal 12 to help developing countries to move towards more sustainable consumption and production patterns.

Remarkable methodological and application advances have been made at the international level and Argentina has not been alien to this development. However, globalization itself raises the need for common criteria and databases that allow specialists in each area to have reliable information to carry out their studies (Perez 2016). Potting et al. (2001) state that various authors call for further development in some impact categories so that they come closer and closer to measuring real damage to the environment 
and take into account temporal and spatial variability. To ensure that the results of an LCA are consistent, methods and their models must be continuously updated and the trend is to regionalize CFs (Morelli et al. 2018; Civit 2009; Potting and Hauschild 2006).

By 2009, Civit stated that LCA studies had been carried out in the national context, although they had been limited by having to select among impact assessment methods that have been developed in contexts different from those of application, even in regional categories such as eutrophication, since sitedependent factors have not been developed for the region. This highlights the need for local or regional inventories and LCIA models that include regional characteristics.

In Latin America, and specifically in Argentina, there are some precedents for the development of impact indicators for regional categories: water use in the wine chain (Civit et al. 2018), land acidification (Civit et al. 2014), desertification (Civit et al. 2013; Núñez et al. 2010), terrestrial eutrophication and land use (Civit 2009). However, there is still a lack of LCA studies on a national scale, in regions where this category may have environmental significance. Particularly, terrestrial eutrophication has not yet been explored in the field of LCA in Argentina, with only the regional precedent of the work of Civit (2009). Therefore, it is imperative to analyze the terrestrial fate and transport of land-applied nutrients, as the terrestrial eutrophication model is largely absent from the LCIA despite its importance for agriculture and other land-use sectors (Azevedo et al. 2013). The objective of this work is to analyze spatially the eutrophication category, in the context of LCA, in order to know the state of the art of the subject and to identify the research needs for the region, focusing particularly on terrestrial eutrophication.

\subsection{CHARACTERIZATION OF ENVIRONMENTAL IMPACTS}

To characterize the potential impacts of substances released throughout the life cycle of a product, process or activity, impact models make use of CFs. This CFs represent the consequences of an environmental intervention on a receptor in a "cause-effect" chain, defining midpoint and endpoint factors. The impact of the emission of a pollutant or toxic substance has three dimensions which are fate, exposure and effect and therefore various LCIA methods have been proposed (Civit 2009).

Morelli et al. (2018), express that without quantifying the fate, transport and loading of sitespecific nutrients at appropriate spatial scales, the relevance of the for eutrophication may be limited. On the other hand, current characterization models combine marine and freshwater environments into a single impact category, or employ the simplifying assumption that $\mathrm{P}$ is limiting in freshwater ecosystems and $\mathrm{N}$ is limiting in marine ecosystems. However, and current studies indicate that it is important to provide management for both $\mathrm{N}$ and $\mathrm{P}$ (Conley et al. 2009; Paerl and Scott 2010; Davis et al. 2015). More sophisticated LCIA methodologies have begun to be disseminated that take into account not only the 
quantity of emissions produced, but also the place where they are released, their fate and the damage they produce, whether on the natural or artificial ecosystem or on human health (Civit et al. 2006).

\subsection{EUTROPHICATION}

Eutrophication is defined as the abnormally high nutrient enrichment of an ecosystem (Olivera et al. 2016). It occurs when nitrogen $(\mathrm{N})$ and phosphorus $(\mathrm{P})$ compounds that have been emitted by natural or anthropogenic sources are deposited, then reach the soil or water bodies causing a harmful effect such that it modifies the living conditions of the different species that inhabit and develop in them (Morelli et al. 2018; Civit 2009; Finnveden and Potting 1999). In freshwater ecosystems, eutrophication manifests itself with decreased dissolved oxygen and algal blooms that give a characteristic greenish color and is a consequence of increased $\mathrm{P}$ concentration, while in marine ecosystems it results from increased concentration of $\mathrm{N}$ compounds (Civit 2009). If inputs of eutrophying substances exceed the capacity of ecosystems to assimilate these inputs there may be changes in habitat (Hassan et al. 2005). In the last century, increased emissions of nitrogenous compounds from agriculture and industry have increased atmospheric $\mathrm{N}$ deposition in semi-natural ecosystems (Erisman et al. 2013; Galloway et al. 2008) with consequences for biodiversity (Dise et al. 2011; Bobbink et al. 2010). In this regard, excess $N$ can change the structure and function of N-limited terrestrial ecosystems, favoring a (typically) restricted number of adapted species (Henderson 2015).

In Payen et al. (2019) indicate that although eutrophication occurs naturally, the LCIA focuses on connecting emissions from anthropogenic sources, with the impacts of eutrophication. Inorganic $\mathrm{P}$ and $\mathrm{N}$ compounds are the major contributors to eutrophication: phosphate $\left(\mathrm{PO}_{4}{ }^{3-}\right), \mathrm{NH}_{3}$ or $\mathrm{NH}_{4}{ }^{+}$(ammonia and ammonium), $\mathrm{NO}_{3-}$ (nitrate) and gaseous nitrogen oxides (NOx) (Henderson 2015). Aquatic (freshwater and marine) and terrestrial eutrophication are among the impact categories assessed in LCA studies to determine the environmental profile of products, processes and activities, and are included in all models used in the LCA phase. They represent a regional environmental impact, which means that site-based modeling may be necessary for an accurate representation of impacts (Henryson et al. 2017). Until a few years ago, eutrophication was considered as a single impact category. In 1992 that the difference between terrestrial and aquatic eutrophication was made explicit, because terrestrial ecosystems are affected by the contribution of emissions of $\mathrm{N}$ compounds ( $\mathrm{N}$ oxides and ammonia) emitted into the air throughout the life cycle of products, processes or activities, by atmospheric deposition or nitrification (Civit 2009). The time scales over which eutrophying emissions reach and impact a receiving site vary by compound and emission compartment (Galloway 2003).

Given that Argentina has an extensive bioclimatic variability and that it is a producer of raw materials and intermediate products that are incorporated into various production systems in different 
parts of the world, when assessing impacts it is necessary to have factors that characterize the potential effect that the environmental intervention has in one place and not in another. Therefore, due to the high variability of eutrophication impacts (Helmes et al. 2012), approaches that provide spatial differentiation are preferable (Payen et al. 2019).

\section{METHODS}

The bibliographic review was carried out through the search of different academic papers, using the following search engines: Google Scholar, Science Direct, Springer Link, Scielo, REDIB, OAJI, DOAJ, JSTOR, Latindex, Publindex, Dialnet and Redalyc. We also reviewed the proceedings of scientific events, such as the Argentine Life Cycle Meeting (ENARCIV), Argentine Association of Renewable Energies and Environment (ASADES), Meeting of the International Center for Earth Sciences (E-ICES), Meeting of Engineering Researchers and Teachers (ENIDI) and pages of the Food and Agriculture Organization (FAO), Society of Environmental Toxicology and Chemistry (SETAC), National Institute of Agricultural Technology (INTA), Life Cycle Initiative, among others related to the subject. Previously, key words were determined as a search strategy (in Spanish and English). These were combined in the fields "title", "abstract" and "keywords" considering papers published between 1990 (consolidation of the LCA) and 2020. In the field "without the words" "heavy metals, construction and electrical energy" were filled in, since the search engines produced results that were not directly related to the objective of the research. The words selected were:

1. Eutrophication and Life Cycle (or Life Cycle Analysis)

2. Eutrophication and Life Cycle Assessment (or Life Cycle Impact Assessment)

3. Eutrophication and indicators

4. Aquatic eutrophication and Life Cycle

5. Marine eutrophication and Life Cycle

6. Terrestrial eutrophication and Life Cycle

7. Eutrophication and regional impact indicators

8. Regionalization of impacts and Life Cycle

To select the appropriate bibliography, we first reviewed the titles, abstracts and keywords to identify the type of information contained in each one. Next, different essential aspects were considered to process the information, such as: whether it was a theoretical or application case, where it was applied, whether it was framed within the LCA and LCIA methodology, and if so, what methods and models were used, what kind of eutrophication, whether it was studied at the midpoint or endpoint level, and finally, 
differentiation $^{1}$ and aggregation ${ }^{2}$ (Fig. 1). These data, by means of the statistical tool offered by the Excel program (2013), allowed the consecutive analysis of the bibliography found.

Fig. 1 Information processing scheme

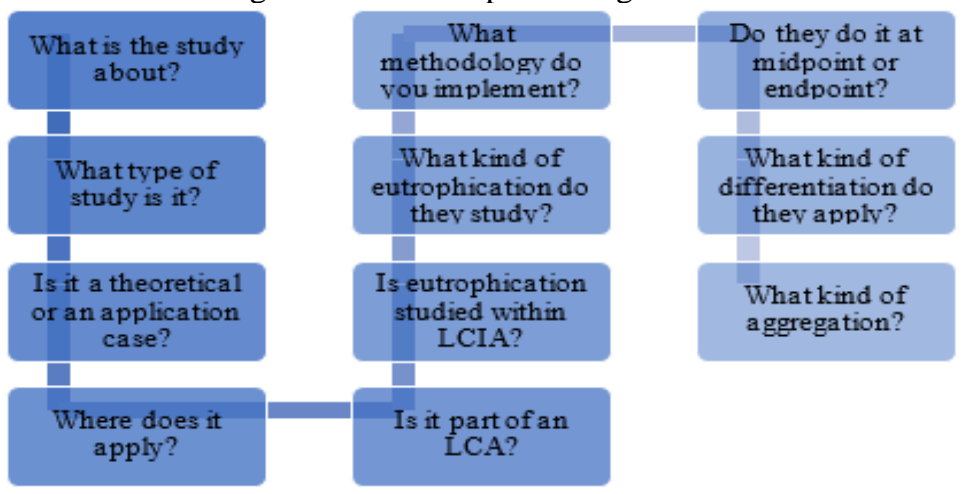

\section{RESULTS AND DISCUSSION}

\subsection{MAIN CHARACTERISTICS OF EUTROPHICATION STUDIES}

From the initial search, out of 4556 studies found, 95 (additional data are given in Online Resource 1) were selected that responded to the interests sought, developed in the field of LCA, as set out in ISO 14040 (2006a) and 14044 (2006b). These include research articles, review articles, discussions, case studies, state of the art, commentaries, analyses, reports, critical reviews, meeting reports, doctoral theses, letters to the editor, global guides, books and chapters, scientific-technical support, abstracts at scientific events and methodology reports. Table 1 shows that there are few research papers that analyze aquatic and terrestrial eutrophication categories in the same study. There is an analysis of aquatic eutrophication, whether freshwater or marine, on the one hand, and terrestrial eutrophication on the other.

Table 1 Number of papers published by topic. 1990-2020 series.

\begin{tabular}{cccc}
\hline & & \\
& & \\
& & \\
& Topics & Abbreviations & Number of papers \\
\hline & Life Cycle Analysis & LCA & 17 \\
\hline & Life Cycle Impact Assessment & LCIA & 17 \\
\hline In the context & Eutrophication & E & 5 \\
of LCA & Freshwater eutrophication & FE & 11 \\
& Marine eutrophication & ME & 6 \\
& Terrestrial eutrophication & TE & 5 \\
& Aquatic and terrestrial eutrophication & AE+TE & 1 \\
& Methods & M & 28 \\
& Indicators & I & 5 \\
\hline
\end{tabular}

1 According to Klopffer (1996), the main problem with lifecycle assessment consists in the absence of true relationships between interventions and environmental effects. The interventions established in the inventory analysis are expressed in amounts per functional unit, and in principle nothing is known about the source-strength and variation over time of the examined processes. Due to this lack of differentiation, which is inherent to LCA, no environmental concentrations can be predicted and, as a consequence, it does not seem possible to evaluate whether a no-effect level is surpassed. However, Potting and Hauschild (1997) argue that it is possible to say something sensible about the surpassing of no-effect-levels and the expected occurrence of actual impact without precise information about the resuiting environmental concentration.

2 Verones et al. (2019) recommend that method developers explore approaches for assessing uncertainty associated with different levels of spatial, temporal, or archetypal aggregation to identify optimal assessment scales. The uncertainty might arise from either upscaling (increasing spatial, temporal, or any other scale by aggregation) or downscaling (decreasing spatial, temporal, or any other scale by increasing resolution). 
The selected "LCA" papers provide a framework for analyzing the study of eutrophication and putting it into context as the state of the art. For this reason, those that were not directly related to the impact category under study were excluded

Temporally, there were years in which scientific production on the subject increased (Fig. 2). Thus, we can observe the appearance of works from 1997 onwards, no scientific production on the subject in the period 1990-1996. Klöpffer (2014), in relation to SETAC, expresses that although its structure was modified during standardization by ISO, the basic discussions took place in a relatively short period between 1990 and 1993. Nevertheless, SETAC has continued to provide a forum for discussion of LCIA and related life cycle methods. Together with the United Nations Environment Programme (UNEP) a joint project, the "UNEP/SETAC Life Cycle Initiative" (Töpfer 2002) was founded in 2002 leading to a globalization of life cycle methods.

Fig. 2 Number of papers published per year. 1990-2020 series

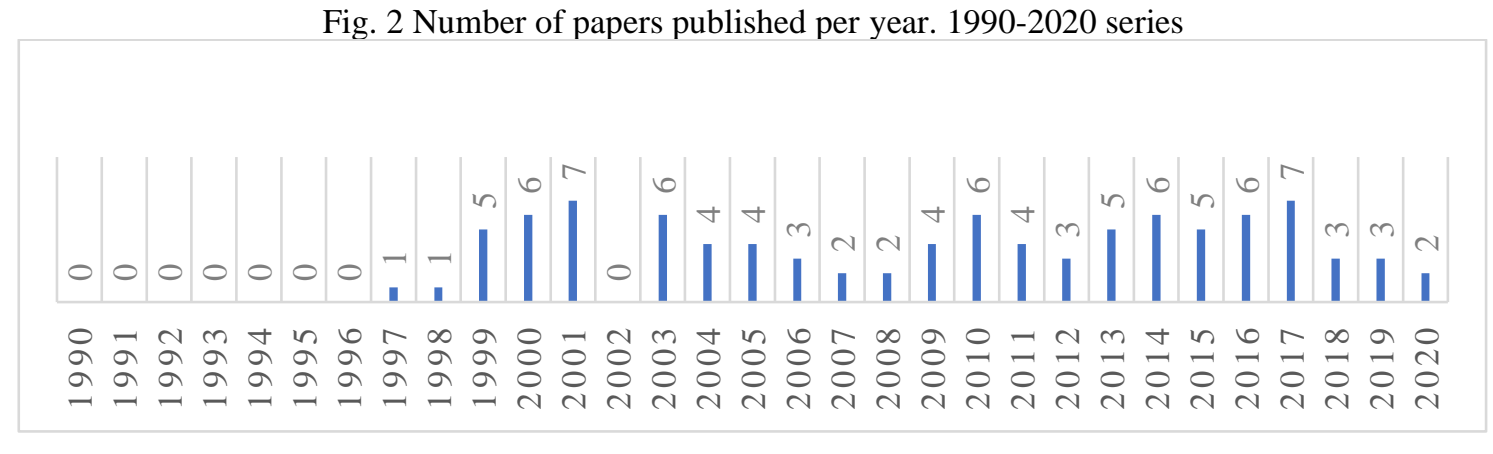

Spatially, the geographical distribution of eutrophication studies has been mostly concentrated in European countries, with a deficiency in South American countries (Fig. 3). This distribution considers both application and theoretical sites, taking into account the place of origin of the authors. Of 95 studies, $55 \%$ are concentrated on the European continent, followed by $23 \%$ with worldwide application, North America (12\%), South America (6\%), Asia (3\%), Oceania (1\%) and finally Africa (0\%). These data show the need to carry out LCA work on the impact of eutrophication on aquatic and terrestrial ecosystems in the countries of the South.

Fig. 3 Number of published papers by continent. 1990-2020 series

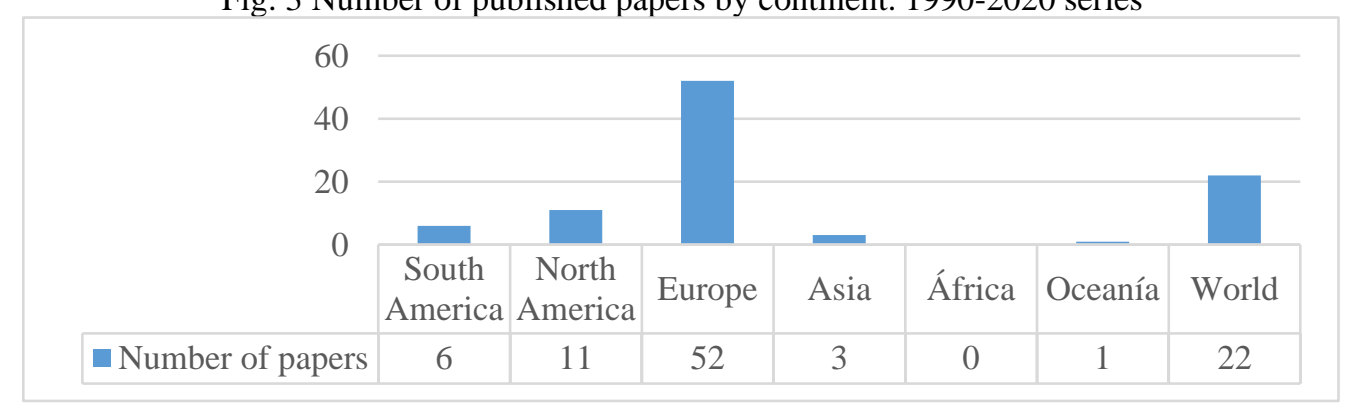


ISO 14040 (ISO 2006a) establishes three general environmental categories to be addressed in LCIA, which are human health, resource use and ecological consequences. Indeed, of the 95 papers selected, $29 \%$ (28) study up to the midpoint, 36\% (34) reach the endpoint and 35\% (33) not applicable CFs (Fig. 4). At this point, it is suggested to provide CFs for both the midpoint and the endpoint in relation to eutrophication (Payen et al. 2019), since both types of indicators are useful depending on the decision context (Rosenbaum et al. 2018).

Fig. 4 Number of papers published according to the study or application of CFs. 1990-2020 series

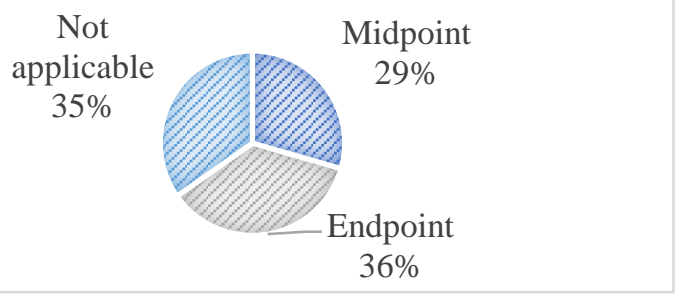

In view of the above, it is possible to differentiate which studies have considered a geographic application and which have been limited to theoretical cases, based on the continent. Thus, 54.7\% (52) of the selected papers were application cases, while the remaining 45.2\% (43) were theoretical cases (Table 2).

Table 2 Number of papers by theoretical or application case and continent. 1990-2020 series Number of papers by theoretical or application case and continent 1990-2020 series

\begin{tabular}{lll} 
Continent & Application case & Theoretical case \\
\hline South America & 3 & 3 \\
North America & 5 & 6 \\
Europe & 24 & 28 \\
Asia & 3 & 0 \\
África & 0 & 0 \\
Oceanía & 1 & 0 \\
World & 16 & 6 \\
\hline Total number of papers & $\mathbf{5 2}$ & $\mathbf{4 3}$ \\
\hline
\end{tabular}

According to the figure above, 52 papers were application cases, $46.1 \%$ of which were located in Europe, $30.7 \%$ worldwide and the rest in the other continents. Theoretical cases are represented by $65.1 \%$ in Europe, 13.9\% worldwide, another 13.9\% in North America and 7\% in South America. Of the 95 papers, only 4 were developed in Argentina (particularly in the province of Mendoza), where 2 of them are application cases focused on terrestrial eutrophication and none on aquatic eutrophication.

For many categories, the impact of a given element depends on where that flow occurs and has site-dependent CFs (Potting and Hauschild, 2006), where not taking them into account can give misleading results (Azevedo et al. 2013; Potting and Hauschild 2006). Therefore, spatial differentiation is considered an important step to improve the LCA methodology (Hellweg and Milà i Canales, 2014). 
However, several authors call for further development in some impact categories so that they also take into account temporal variability (Schmid 2008; Seppälä et al. 2001). Specifically, it is observed that of the selected papers, $49 \%$ (46) do not apply/correspond to a type of differentiation in their analyses, $45 \%$ (43) work with spatial differentiation, 6\% (6) combine spatial and temporal and 0\% with temporal differentiation only (Fig. 5).

Fig. 5 Number of published papers by type of differentiation. 1990-2020 series

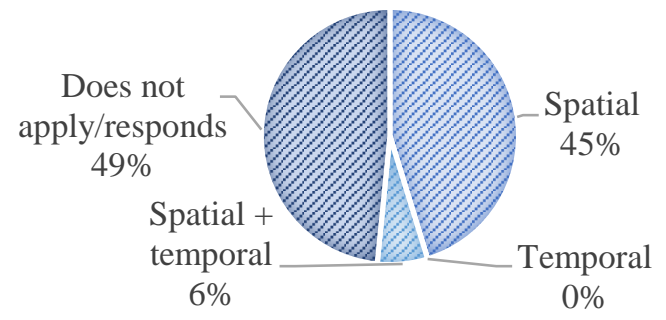

The spatial aggregation is dependent on the object of research, so it differs according to the study and place of application, standing out among the selected works:

$\rightarrow$ global, continental, by country, different regional scales;

$\rightarrow$ climatic zones;

$\rightarrow$ terrestrial ecozones;

$\rightarrow$ agricultural soils, crops, agricultural systems;

$\rightarrow$ oceans, marine and coastal zones and ecosystems, watersheds, river basins, estuaries, estuaries;

$\rightarrow$ natural areas;

$\rightarrow$ economic sectors.

Despite recent efforts to capture the effects of eutrophication on LCIA, there is no clear consensus on the use of a specific impact indicator and methods that do not take fate into account and lack modeling of effects are still being used. There is a need to identify and achieve consensus on scientific matters (Frischknecht et al. 2019). The Life Cycle Initiative recommends employing spatially explicit models with global coverage, aggregating CFs using agricultural, non-agricultural, or global emissions weights, and using existing environmental concentrations for effects models. Guidance is needed on which quantitative life cycle-based indicators are best suited to measure and monitor impacts on human health, ecosystems and natural resources (Jolliet et al. 2018; Frischknecht and Jolliet 2016).

Since the beginning of the LCA methodology, several LCIA methods have been proposed (Civit 2009). Consequently, it is necessary to provide guidance to practitioners (Payen et al. 2019). The following methods (and models) are considered in this work: Accumulated Exceedance (AE) (Seppälä et 
al. 2006); CML 2002 (Guinée et al. 2002); EDIP 2003 (Potting and Hauschild 2005); IMPACT 2002+ (Jolliet et al. 2003); IMPACT World+ (Bulle et al. 2019); LC-Impact (Verones et al. 2016); ReCiPe 2008 (Goedkoop et al. 2013, 2009); ReCiPe 2016 (Huijbregts et al. 2017, 2016) and TRACI (Norris 2008; Bare et al. 2003). In relation to the analysis of the selected papers, it is possible to identify several LCIA methods that have been applied or recommended by the authors according to the study context (Table 3). Thus, according to the scope of the research, there are:

Table 3 Methods according to scope of research. 1990-2020 series

\begin{tabular}{llr}
\hline $\begin{array}{l}\text { Methods according to scope of research } \\
\text { 1990-2020 series }\end{array}$ & Endpoint & IMPACT 2002+ \\
\hline Midpoint & AE & IMPACT World+ \\
\hline AE & CARMEN & LC-impact \\
\hline CML, CML 2001, CML 2002 & CML 2001, CML 2002 & LIME \\
\hline CML-IA & ECO-INDICATOR 98, 99 & RAINS-LCA \\
\hline $\begin{array}{l}\text { Assessment) (Decision Analysis } \\
\text { ECO-INDICATOR 99 }\end{array}$ & Ecological & Scarcity \\
\hline ECO-SPEED & Ecopoints 2006) & ReCiPe, ReCiPe \\
\hline EDIP 2003 & EDIP, EDIP 97, EDIP 2003 & 2008, ReCiPe 2016 \\
\hline IMPACT 2002+ & EPS 2000 & TRACI \\
\hline LIME & ILCD 2009 & \\
\hline ReCiPe, ReCiPe 2008 & & \\
\hline TRACI & & \\
\hline
\end{tabular}

Product certification schemes such as EPD (Environmental Product Declarations) or PEF (Product Environmental Footprint) recommend, for example, CML 2002 and ReCiPe 2016. Various authors discuss the best practice for eutrophication and it is necessary to select that method that suits the conditions at the study site. Bach \& Finkbeiner (2017) and Hauschild et al. (2013) indicate that the recommended method for characterization at the midpoint level is the AE model, as documented in Seppälä et al. (2006) and Posch et al. (2008), which models the AE of critical N loads in sensitive terrestrial ecosystems. Now, for aquatic eutrophication, Bach \& Finkbeiner (2016) recommend ReCiPe from Goedkoop et al. (2009), where the model considers the change in substance concentration, to name a few authors. As for the models, ECOSENSE, EMEP, EMEP/MSC-W, EUTREND, fate and transport (F\&T) models, Mechanistic biological model, NEWS 2, NEWS 2-DIN, RAINS, RUSLE, have been identified for the midpoint, while for the endpoint, the following have been highlighted: ANOVA, ECOSENSE, EUTREND, Tropospheric GEOS-Chem model, WMI (Windrose Model Interpreter), LUCAS, MEEuP, NEWS 2-DIN, OVERSEER nutrient budget model, USES-LCA 2. 0, USLE-Swiss Agricultural Life Cycle Analysis (SALCA).

Morelli et al. (2018) perform a critical review of eutrophication models for LCA. They indicate that historically, LCA studies have estimated eutrophication impacts based on global or continental average models. However, the science is advancing toward methods that utilize location-specific 
characteristics to better characterize and quantify nutrient fate and transport through air, land, and water, as well as the associated ecosystem responses.

Currently, Payen et al. (2019) suggest that for freshwater eutrophication the mid-level indicator measures potential freshwater eutrophication in P equivalents (Peq) based on the fate model of Helmes et al. (2012). While, the CFs at the endpoint level calculate damages (PDF .m3.yr) to freshwater ecosystems based on the above fate plus the inclusion of the effect of total $\mathrm{P}$ changes in autotrophs, aquatic invertebrates and fish from Azevedo et al. (2013). For marine eutrophication, the midpoint indicator measures marine eutrophication potential in N-equivalents (Neq) based on Cosme et al. (2017b). At the endpoint level, CFs calculate damage (PDF. $\mathrm{m}^{3}$.yr) to benthic ecosystems for six heterotrophic taxonomic groups across five climate zones based on Cosme et al. (2017a). For terrestrial eutrophication, no consensus has yet been reached. It is recommended to use regional inventory data when possible or to perform an uncertainty analysis. This denotes the importance of matching inventory databases with available impact models (Payen et al. 2019). Regionalization has the potential to identify any regional occurrences of environmental unsustainability that would be overlooked through global assessment, given the spatially uneven distribution of carrying capacity as well as environmental impacts of many elementary flows (Bjørn et al. 2020).

\subsection{MAIN CHARACTERISTICS OF EUTROPHICATION STUDIES IN TERRESTRIAL ECOSYSTEMS}

The inclusion of terrestrial eutrophication in LCIA methodologies was later than in the case of aquatic. Thus, Lindfors et al. (1995) were the first to consider it, proposing the use of CFs for aerial nitrogen compounds deposited on the soil. According to the analysis carried out, of the 95 papers selected, only 6 are focused on terrestrial eutrophication, and Table 4 shows the most relevant characteristics of each one. 
Table 4 Main characteristics of terrestrial eutrophication studies

\begin{tabular}{|c|c|c|c|c|c|c|}
\hline Reference & Place & $\begin{array}{c}\text { Is it a case } \\
\text { of } \\
\text { application? }\end{array}$ & Dimensions & Differentiation & Aggregation & LCIA methods and models \\
\hline $\begin{array}{l}\text { Huijbregts } \\
\text { et al. } \\
(2000)\end{array}$ & Europe & Yes & $\begin{array}{l}\text { Fate, } \\
\text { exposure } \\
\text { and effect } \\
\text { (endpoint) }\end{array}$ & $\begin{array}{l}\text { Temporal and } \\
\text { spatial }\end{array}$ & $\begin{array}{c}\text { Europe and a } \\
\text { number of } \\
\text { European regions }\end{array}$ & $\begin{array}{l}\text { Spatially explicit regional } \\
\text { air pollution information } \\
\text { and simulation model } \\
\text { (RAINS-LCA) }\end{array}$ \\
\hline $\begin{array}{l}\text { Seppälä et } \\
\text { al. (2006) }\end{array}$ & Europe & Yes & $\begin{array}{l}\text { Emissions } \\
\text { (midpoint) }\end{array}$ & $\begin{array}{l}\text { Spatial: site- } \\
\text { dependent; } \\
\text { temporal }\end{array}$ & $\begin{array}{c}35 \text { European } \\
\text { countries and } 5 \\
\text { sea areas for } 2002 \\
\text { emissions and } \\
\text { emissions } \\
\text { predicted for } 2010\end{array}$ & $\begin{array}{l}\text { EMEP Lagrangian model. } \\
\text { EcoSense. RAINS. } \\
\text { The are chosen category } \\
\text { indicator, AE and } \\
\text { unprotected ecosystem area } \\
\text { (UA). }\end{array}$ \\
\hline $\begin{array}{l}\text { Civit et al. } \\
\quad(2006)\end{array}$ & $\begin{array}{l}\text { Mendoza, } \\
\text { Argentina } \\
\text { (South } \\
\text { America) }\end{array}$ & Yes & $\begin{array}{l}\text { Emissions } \\
\text { and } \\
\text { depositions } \\
\text { (midpoint) }\end{array}$ & Spatial & $\begin{array}{l}\text { Regional level: } \\
\text { Mendoza }\end{array}$ & $\begin{array}{c}\text { EDIP } 2003 \text { (Program ISC } \\
31)\end{array}$ \\
\hline $\begin{array}{l}\text { Schmid } \\
(2008)\end{array}$ & $\begin{array}{l}\text { Galicia, } \\
\text { Spain } \\
\text { (Europe) }\end{array}$ & Yes & $\begin{array}{l}\text { Emission, } \\
\text { deposition } \\
\text { and } \\
\text { regional } \\
\text { critical load } \\
\text { (midpoint) }\end{array}$ & Spatial & $\begin{array}{l}\text { Regional level: } \\
\text { Galicia }\end{array}$ & $\begin{array}{c}\text { AE was used as the category } \\
\text { indicator }\end{array}$ \\
\hline $\begin{array}{l}\text { Civit } \\
(2009)\end{array}$ & $\begin{array}{l}\text { Mendoza, } \\
\text { Argentina } \\
\text { (South } \\
\text { America) }\end{array}$ & Yes & $\begin{array}{c}\text { Emissions, } \\
\text { depositions } \\
\text { and } \\
\text { dispersion } \\
\text { (midpoint) }\end{array}$ & $\begin{array}{l}\text { Spatial: site- } \\
\text { dependent }\end{array}$ & $\begin{array}{l}\text { Regional level: } \\
\text { Mendoza }\end{array}$ & $\begin{array}{l}\text { The impact model proposed } \\
\text { here is based on the } \\
\text { proposal of Potting et al } \\
\text { (2004) and was adapted and } \\
\text { modified according to the } \\
\text { needs identified and the } \\
\text { characteristics of the } \\
\text { ecosystems present in the } \\
\text { region studied }\end{array}$ \\
\hline $\begin{array}{l}\text { Gallego et } \\
\text { al. (2011) }\end{array}$ & $\begin{array}{l}\text { Galicia, } \\
\text { Spain } \\
\text { (Europe) }\end{array}$ & Yes & $\begin{array}{l}\text { Deposition, } \\
\text { emissions } \\
\text { and critical } \\
\text { loads } \\
\text { (midpoint) }\end{array}$ & Spatial & $\begin{array}{l}\text { Regional level: } \\
\text { Galicia }\end{array}$ & $\begin{array}{c}\text { AE was used as the category } \\
\text { indicator }\end{array}$ \\
\hline
\end{tabular}

Among the works cited, it is observed that they correspond between 2000 and 2011, with greater development and application in Europe (66.6\%), followed by South America, particularly in the province of Mendoza (33.3\%). Considering the scope, 4 (66.6\%) works reached the midpoint and $2(33.3 \%)$ the endpoint. In turn, all have considered site-dependent spatial differentiation, with different levels of aggregation and, in some cases, temporal differentiation. Site-dependent spatial differentiation is made by distinguishing between source types and the environment that will then receive the deposition, knowing a priori their sensitivity to exposure. The geographical scale is defined at the level of regions or countries and varies between 50-500 km (Potting and Hauschild 2006).

Methodologically, Huijbregts et al. (2000) describe the spatially explicit regional air pollution information and simulation model (RAINS-LCA), which was developed for the calculation of acidification and terrestrial eutrophication potentials for Europe and a number of European regions, taking 
fate, background depositions and effects into account. The results indicate that it is important to use region-specific and time-specific terrestrial acidification and eutrophication potentials.

For their part, Seppälä et al. (2006) chose as category indicator the AE, was computed according to the calculation methods developed in the work under the United Nations Economic Commission for Europe (UNECE) Convention on Longrange Transboundary Air Pollution (LRTAP). Sulphur and N depositions to $150 \times 150 \mathrm{~km}^{2}$ grid cells over Europe were calculated by source-receptor matrices derived from the EMEP Lagrangian model of long-range transport of air pollution in Europe. For the comparison, the results based on the use of UA indicator were calculated by $10 \%$ and $50 \%$ reductions of emissions that corresponded to the common practice used in the previous studies. Thus, the comparison between country-dependent CFs calculated by the AE and UA indicators showed that these two approaches produce differences between characterisation factors for many countries/areas in Europe.

Schmid (2008) developed regional factors for aquatic and terrestrial eutrophication in Galicia, Spain. He established AE values, reflecting the amount of $\mathrm{N}$ accumulated above the critical load, as a category indicator, based on nitrogenous compound deposition levels and the sensitivity of their terrestrial ecosystems, taking as a starting point the method developed by Seppälä et al. (2006). In fact, the factors obtained were lower than those available for Spain, which demonstrates the importance of calculating factors at the regional level. Similarly, Gallego et al. (2011) used the AE and required actual values of deposition, emissions and critical loads. The results obtained confirm that it is a suitable category indicator for terrestrial eutrophication estimation.

As a regional antecedent, Civit et al. (2006) presented the results obtained from the modeling of $\mathrm{N}$ deposition in soils and its comparison with the threshold values for a representative crop of the region (garlic), a step prior to the determination of equivalence factors for the terrestrial eutrophication impact category for the arid central-western region of Argentina. The results show that under the conditions analyzed, eutrophication would not occur in these crops, since in no case is the threshold value exceeded. Later, Civit (2009) developed an impact model based on the proposal of Potting \& Hauschild (2006), was adapted and modified according to the needs and characteristics of the arid region of central-western Argentina. The model calculated the CFs in terms of the effect on the decline in production that could be caused by the deposition of $\mathrm{N}$ compounds, comparing the deposition of these substances with the threshold values of the species that exist in these ecosystems: grapevine and garlic. As results, he obtained that the impact model developed has allowed to verify the applicability of the model in definite cases of impact assessment and to demonstrate that the use of generic factors or worse, foreign site-dependent factors, can effectively lead to obtain erroneous results overestimating the impact considered. The procedure followed to determine the CFs of terrestrial eutrophication could be applied to other regions of the national territory, taking as a basis the most representative crops and their respective $\mathrm{N}$ thresholds in each one of them. 
It is observed that the $\mathrm{AE}$ indicator is widely used to determine the impacts of terrestrial eutrophication in different regions of the world, considering the spatial differentiation and the particular characteristics of the sites under study.

\subsubsection{Accumulated Exceedance in terrestrial eutrophication studies}

As explained in Table 4, the use of the AE indicator (number of $\mathrm{N}$ equivalents that are above the critical load) stands out among the LCIA methods.

In the last century, enhanced emissions of nitrogenous compounds caused by agricultural and industrial activities have increased atmospheric $\mathrm{N}$ deposition in natural and semi-natural ecosystems across the world (Erisman et al., 2013; Galloway et al., 2008). As N deposition increases, it is normal for $\mathrm{N}$ availability in the soil to increase significantly, often resulting in a crossing of an $\mathrm{N}$ saturation threshold (Dise \& Wright 1995; Brenner et al. 2005; Nilsson et al. 2006; Stevens et al. 2006), which in turn often leads to increased $\mathrm{N}$ losses through flushing (Dise \& Wright 1995). Crossing this threshold is often considered as an indicator of negative $\mathrm{N}$ effects, as $\mathrm{N}$ availability would be higher than the ecosystem is able to process (Pilkington et al. 2005; Fowler et al. 2013). The responses of plant communities to $\mathrm{N}$ deposition vary depending on the environmental context (Perring et al. 2018; Simkin et al., 2016; Vellend et al., 2017).

In the work of Huijbregts et al. (2000), the hazard index above and below the critical loads is used as CFs, where the latter can be defined as a quantitative estimate of an exposure to one or more pollutants below which significant harmful effects on specified sensitive elements of the environment do not occur, according to present knowledge". Among several results, they obtained that a larger dispersion is found among the region-specific terrestrial eutrophication potentials of $\mathrm{NH}_{3}$ compared to the terrestrial eutrophication potentials of NOx, because the transport potential of NOx is higher than that of $\mathrm{NH}_{3}$. The maximum regional differences between the terrestrial eutrophication potentials are up to 1.5 orders of magnitude, depending on the substance and the scenario chosen: "above and below critical load" or "below critical load only". Something to consider is that, in general, critical ecosystem loads for $\mathrm{N}$ are high and are due to immobilization and denitrification of $\mathrm{N}$ in the soil and net uptake by plants (UBA 1996).

Seppälä et al. (2006), using emitter-receptor matrices based on the Lagrangian long-range air pollutant transport model developed by EMEP and the most updated critical load moment data (Hettelingh et al. 2004), developed CFs for 35 European countries. In this case they took into account as a category indicator the variation that occurs in $\mathrm{AE}$ with a marginal variation in emissions in a given country and year (Schmid 2008). The authors considered calculating corresponding CFs for European countries and five maritime areas. They indicate that the prerequisite for calculating the AE indicator type for a region is the definition and calculation of the exceedance of the critical load of a single ecosystem. As reference 
emissions, we used the national emissions for the year 2002 as well as the predicted emissions for the year 2010, as reported by EMEP (Vestreng et al. 2004). Among their results, they show that the indicator produces reliable CFs for applications requiring small changes in national emissions, which are typical of LCIA applications.

On the other hand, Schmid (2008) indicates that AE is one of the most widely used impact category indicators. The author has established the values based on the deposition levels of nitrogen compounds and the sensitivity of their terrestrial ecosystems to eutrophication, using the regional emission, deposition and critical load values for the calculation of CFs. In his work, he has shown that $\mathrm{AE}$ is a good indicator, since it allows obtaining stable CFs and negligible characterization errors when evaluating minor variations in emissions $(<100 \mathrm{t})$, which are those that usually occur in LCA. The most important advantage is that it allows evaluating how the impact varies when the amount of deposition exceeding the critical load changes (Seppälä et al. 2006) and thus corrects one of the disadvantages of approximationbased methodologies. In the specific case of this study, the excess is defined as the amount of $\mathrm{N}$ deposited above the critical load, for Galicia in 2001, using NOx and NHx CFs. In Gallego et al. (2011), the results obtained confirm that $\mathrm{AE}$ is a suitable category indicator for the estimation of terrestrial eutrophication.

As recommendations and perspectives, Gallego et al. (2011) express that a comprehensive comparison of $\mathrm{AE}$ and risk index (HI) methodologies for terrestrial eutrophication would be interesting, as both apply the above-threshold-only approach (Huijbregts et al. 2000; Seppälä et al. 2006). Civit (2009) indicates that while HI uses a scaling coefficient to quantify the exceedance and evaluates the marginal changes that occur in that coefficient, $\mathrm{AE}$ is based on the absolute difference between deposition and the critical load or tolerable threshold and evaluates the marginal changes in cation exchange capacity that occur. Another indicator that appears in Seppälä et al. (2006) is the UA. The authors note that it is commonly used as a category indicator in the determination of CFs, although it is only suitable for large changes in emissions and does not lead to environmental benefits in terms of CFs if deposition after emission reductions is still higher than the critical load.

\subsubsection{Importance of the application of the Accumulated Exceedance in pampean agroecosystems in} Argentina

While the European Union (EU) strategy on air pollution aims to achieve a 35\% reduction in the ecosystem area exceeding critical loads of eutrophication by 2030, relative to 2005 (EC, 2013a), this would only be achieved if the maximum number of technically feasible reduction measures were implemented (EC, 2013b). On the other hand, in the eastern United States, $\mathrm{N}$ deposition is declining from historical peaks in the 1970s and 1980s as a result of stricter air quality standards associated with the Clean Air Act of 1990 and subsequent policy (Burns et al. 2011). However, deposition is increasing or 
unchanged in the western United States, and there is a shift in the composition of deposition toward more reduced forms of $\mathrm{N}$ nationally ( $\mathrm{Li}$ et al. 2016). Furthermore, even though deposition may be declining in some regions such as the east, these rates still far exceed pre-industrial rates and the estimated sensitivities of many ecological endpoints in the region (Baron et al. 2011, Pardo et al. 2011a).

In the case of Latin America, current and future agricultural practices are and will be critical in determining the human impact on the $\mathrm{N}$ cycle, due to the importance of the agricultural sector in the economies of most of the region (Martinelli et al. 2006). At the same time, differences both in climatic and edaphic properties as well as socioeconomic policies make generalization difficult in terms of predicting the consequences of human activity in this region (Austin et al. 2006). Argentina is currently considered one of the major agricultural regions of the world, with most activity centered in the Pampa region (Hall et al. 1992). This points to the need to apply regional factors in southern countries, where there is insufficient data on eutrophication in the aquatic and terrestrial ecosystems of these regions.

Pereyra (2012) states that the great eco-environmental variability of Argentina is materialized in a complex mosaic of landscapes and soils, being able to differentiate 12 regions, each characterized by a particular association of soils resulting from a specific arrangement of formation factors and pedogenetic processes. That the incidence or degree of determination of a given factor varies from one region to another and even within the same region.

Dominguez \& Rubio (2019) provide an overview of the main agricultural characteristics of the different regions of the country. In the northwestern region, the climate favors the development of subtropical agriculture. In the Cuyo Region, intensive agriculture under irrigation predominates. In the Patagonian Region, the production of edible crops is strongly limited by extreme climatic conditions. The central zone comprises the Pampean Region, characterized by highly favorable conditions for agriculture. Argentina has some of the most fertile soils in the world, especially those located in the Pampean Region. In this sense, soils constitute one of the greatest assets of Argentina and give the country the capacity to produce food for more than ten times its current population (Rubio et al., 2019).

The expansion and intensification of agriculture has probably been the most remarkable fact of Argentine agriculture in recent decades. This has been mainly associated with the reconversion of new areas with no agricultural background; the reconversion to full cropping of land previously rotated with livestock; the dramatic increase in the area planted with soybean; the expansion of double cropping; and the increase in the area cultivated under no-tillage systems (Magrin et al. 2005; Paruelo et al. 2005; Boletta et al. 2006), eliminating hundreds to millions of hectares of natural forests (Montenegro et al. 2007). Lavado (2016) indicates that degradation processes have different degrees of anthropogenic causality, varying levels of extension and a diverse scale of severity. 
Local extensive agricultural systems continue to show a deficit in nutrient replenishment and some local aquifers have a high concentration of nitrates (Rubio et al. 2019). Thus, it is possible to apply regional CFs for Argentina, where its productive matrix, soil use and management, and international trade, highlight the need to assess the environmental impacts of products, processes or activities on terrestrial ecosystems. Given the environmental variability and diversity of its productive systems, it is considered important to select a minimum set of species representative of each region to apply and evaluate the EA as a category indicator of $\mathrm{N}$ deposition in the region. The work of Civit (2009) in the province of Mendoza, taken as a regional background reference, shows that it is feasible and valid for Argentina to apply regional $\mathrm{CFs}$ such as the $\mathrm{AE}$ and that extrapolation to other regions of the country is possible, considering the environmental and productive characteristics of land use in each of them.

Although this article has not focused particularly on aquatic eutrophication, regional antecedents of eutrophication in lakes and lagoons in Argentina are the basis for its next analysis within the context of Life Cycle Analysis, since no studies have been reported within this methodology. Several authors have recognized that Argentina presents serious Eutrophication problems in some of its lakes and reservoirs (Quirós, 2000) (e.g., Mengo et al., 2019; Espósito et al., 2016; Ledesma et al., 2013; Mariñelarena \& Gómez, 2008).

\section{CONCLUSION}

After an extensive literature review, where 4556 studies related to eutrophication and LCA in recent years were relieved, of which 95 emphasize the importance of spatial analysis, it is evident that further development and updating of studies on this category of impact is required, given that only 6 works are addressed for Latin America and from these, 4 were made in Argentina. Although it is more notorious in the case of aquatic eutrophication, recognizing the large number of watersheds present in the region, environmental mechanisms in terrestrial ecosystems should not be left aside; the advance of the agricultural frontier, changes in soil use and management and the disappearance of natural plant species is a fact present in the soils of the southern region of the American continent. Therefore, the focus placed here on terrestrial eutrophication responds to generate a baseline for the development of research in Argentina, which contributes to regional environmental sustainability. However, it seems striking that the progress of terrestrial eutrophication has not been evenly matched with aquatic eutrophication, considering that it is a very significant environmental problem, due to changes in the functions and composition of N-poor species, so it would be important to elucidate this distinction.

The spatial regionalization of the mechanisms of eutrophication impact, according to the particularities of the receiving ecosystems in Argentina where the different economic activities occur, with applicability in the LCIA, is considered essential. Otherwise, the scarcity or absence of regional 
values would require the use of CFs developed for other sites, which could generate unrepresentative results in a large region with variability in its bioclimatic characteristics.

Particularly, the study of terrestrial eutrophication in Argentina through the application of the accumulated surplus indicator is feasible by selecting a minimum set of cultivated or natural species to evaluate whether $\mathrm{N}$ depositions exceed the critical threshold in each of them and generate an environmental impact, or if fortunately, this category of impact is not relevant. This research can be further developed, continuing with the characterization of the ecosystems receiving the emissions. The data obtained will allow the selection of the most appropriate midpoint impact model to adapt to regional conditions, following the guidelines agreed upon at the Pellston Workshop that took place in May 2018, in Valencia, Spain (Payen et al. 2019), as it is the current Initiative that encompasses different professionals in the life cycle field.

The need and importance of this research and the availability of potentially usable methods have been clearly shown. However, the task is not simple. It is not the simple application of an existing method to a new case, but requires facing a series of challenges, among them, the regional productive diversity in the analysis of life cycle inventory data, the consideration of impact mechanisms in aquatic and terrestrial ecosystems, the study of fate, transport and deposition of limiting substances in receiving areas, the generation of site-dependent CFs, due to the regional character of eutrophication, and together with this, the application of spatial and temporal differentiation.

Therefore, this first step suggests that the choice of developing regional indicators within the LCIA stage is visibly justified to carry out research in Argentina, where eutrophication is not yet fully explored in the field of LCA at the regional level. This contribution would generate data to quantify environmental impacts derived from various economic activities.

For our research, the definition of the Accumulated Surplus and the regional characterization factors are fundamental to evaluate what happens with eutrophication in the ecosystems of southern Latin America, particularly in the Pampean agroecosystems region of Argentina. In this way, a precedent would be generated for the study of environmental risks in the region in relation to productive systems.

\section{ACKNOWLEDGEMENTS}

The authors wish to thank the Consejo Nacional de Investigaciones Científicas y Técnicas (CONICET) of Argentina. This article was developed during an Internal Doctoral Fellowship funded by the Agency, within the CLIOPE group "Energy, environment and sustainable development" of the Universidad Tecnológica Nacional-Facultad Regional Mendoza (UTN-FRM), Argentina. 


\section{REFERENCES}

Arena, A. P. (1999). Un instrumento para el análisis y evaluación ambiental de productos y tecnologías. $\mathrm{El}$ análisis de ciclo de vida. Consideraciones metodológicas, usos y limitaciones. ASADES 3.

Austin, A. T., Piñeiro, G., \& Gonzalez-Polo, M. (2006). More is less: agricultural impacts on the N cycle in Argentina. In Nitrogen Cycling in the Americas: Natural and Anthropogenic Influences and Controls. Biogeochemistry, 79: 45-60. 10.1007/s10533-006-9002-1

Azevedo, L. B., Henderson, A. D., Van Zelm, R., Jolliet, O., \& Huijbregts, M. A. J. (2013). Assessing the importance of spatial variability versus 454 model choices in life cycle impact assessment: the case of freshwater eutrophication in Europe. Environmental Science \& Technology, 47(23), 13565-13570. https://doi.org/10.1021/es403422a

Bach, V., \& Finkbeiner, M. (2017). Approach to qualify decision support maturity of new versus established impact assessment methods - 457 demonstrated for the categories acidification and eutrophication. The International Journal of Life Cycle Assessment, 22(3), 387-397. 458 https://doi.org/10.1007/s11367-016-1164-z

Bare, J. C., Norris, G. A., Pennington, D. W., \& McKone, T. E. (2003). TRACI: The tool for the reduction and assessment of chemical and other environmental impacts. Journal of Industrial Ecology, 6: 49-78.

Baron, J. S., Driscoll, C. T., Stoddard, J. L., \& Richer, E. E. (2011). Empirical critical loads of atmospheric nitrogen deposition for nutrient enrichment and acidification of sensitive US lakes. BioScience, 61: 602- 613.

Bjørn, A., Chandrakumar, C., Boulay, A. M., Doka, G., Fang, K., Gondran, N., ... \& Ryberg, M. (2020). Review of life-cycle based methods for absolute environmental sustainability assessment and their applications. Environmental Research Letters, 15(8), 083001.

Bobbink, R., Hicks, K., Galloway, J., Spranger, T., Alkemade, R., Ashmore, M., ... \& de Vries, W. (2010). Global assessment of nitrogen deposition effects on terrestrial plant diversity: a synthesis. Ecological applications, 20: 30-59. https://doi.org/10.1890/08-1140.1

Boletta, P. E., Ravelo, A. C., Planchuelo, A. M., \& Grilli, M. (2006). Assessing deforestation in the Argentine Chaco. Forest Ecology and Management, 228: 108-114. https://doi.org/10.1016/j.foreco.2006.02.045

Brenner, R. E., Boone, R. D., \& Ruess, R. W. (2005). Nitrogen additions to pristine, high-latitude, forest ecosystems: Consequences for soil nitrogen transformations and retention in mid and late succession. Biogeochemistry, 72: 257-282.

Bulle, C., Margni, M., Patouillard, L., Boulay, A. M., Bourgault, G., De Bruille, V., ... \& Jolliet, O. (2019). IMPACT World+: a globally regionalized life cycle impact assessment method. The International Journal of Life Cycle Assessment, 24: 1653-1674. https://doi.org/10.1007/s11367-019-01583-0

Burns, D. A., Lynch, J. A., Cosby, B. J., Fenn, M. E., \& Baron, J. S. (2011). National Acid Precipitation Assessment Program Report to Congress 2011: An Integrated Assessment. US EPA Clean Air Markets Division. 
Civit, B. M. (2009). Sostenibilidad ambiental. Desarrollo de indicadores para su aplicación en estudios de análisis de ciclo de vida en la región árida del centro-oeste argentino. Mendoza, Argentina

Civit, B. M., Arena, A. P., \& Allende, D. (2014). Determination of regional acidification factors for Argentina. The International Journal of Life Cycle Assessment, 19: 1632-1642. https://doi.org/10.1007/s11367-012-0427-6

Civit, B. M., Arena, A. P., \& Puliafito, S. E. (2006). Estudio de deposiciones de nitrógeno en suelos para la evaluación de la eutrofización terrestre en la región centro oeste árida argentina. AVERMA 10.

Civit, B. M., Arena, A. P., Núñez, M., Muñoz, P., Antón, A., \& Rieradevall, J. (2013). Assessing potential desertification environmental impact in life cycle assessment. Part 2: agricultural case study in Spain and Argentina. The International Journal of Life Cycle Assessment, 18: 1302-1315. https://doi.org/10.1007/s11367-013-0582-4

Civit, B. M., Piastrellini, R., Curadelli, S., \& Arena, A. P. (2018). The water consumed in the production of grapes for vinification (Vitis vinifera). Mapping the blue and green water footprint. Ecological Indicators, 85: 236-243. https://doi.org/10.1016/j.ecolind.2017.10.037

Conley, D. J., Paerl, H. W., Howarth, R. W., Boesch, D. F., Seitzinger, S. P., Havens, K. E., Lancelot, C., \& Likens, G. E. (2009). Controlling eutrophication: nitrogen and phosphorus. Science, 323: 1014-1015.

Cosme, N., Jones, M. C., Cheung, W. W., \& Larsen, H. F. (2017a). Spatial differentiation of marine eutrophication damage indicators based on species density. Ecological Indicators, 73: 676-685. https://doi.org/10.1016/j.ecolind.2016.10.026

Cosme, N., Mayorga, E., \& Hauschild, M. Z. (2017b). Spatially explicit fate factors of waterborne nitrogen emissions at the global scale. The International Journal of Life Cycle Assessment, 23: 1286-1296. https://doi.org/10.1007/s11367-017-1349-0

Davis, T. W., Bullerjahn, G. S., Tuttle, T., McKay, R. M., \& Watson, S. B. (2015). Effects of increasing nitrogen and phosphorus concentrations on phytoplankton community growth and toxicity during Planktothrix blooms in Sandusky Bay, Lake Erie. Environmental Science \& Technology, 49: 7197-7207. https://doi.org/10.1021/acs.est.5b00799

Dise, N. B., Ashmore, M., Belyazid, S., Bleeker, A., Bobbink, R., de Vries, W., Erisman, J. W., Spranger, T., \& Stevensand, C. J. (2011). Nitrogen as a threat to European terrestrial biodiversity. In Sutton MA, Howard CM, Erisman JW, Billen G, Bleeker A, Grennfelt P, van Grinsven H, Grizzetti B (Eds.), The European nitrogen assessment. Sources, effects, and policy perspectives, pp 463-493.

Dise, N. B., \& Wright, R. F. (1995). Nitrogen leaching from European forests in relation to nitrogen deposition. Forest Ecology and Management, 71: 153-161.

Dominguez, J., \& Rubio, G. (2019). Agriculture. In G. Rubio, R. S. Lavado \& F. X. Pereyra (Eds.), The Soils of Argentina (pp. 209-238). Springer. https://doi.org/10.1007/978-3-319-76853-3

E. C. (2013a). The Clean Air Policy Package. http://ec.europa.eu/environment/air/clean_air_policy.htm E. C. (2013b). Commission staff working paper - Executive Summary of the impact assessment of The Clean Air Policy Package, SWD. http://eur-lex.europa.eu/legalcontent/EN/TXT/PDF/?uri=CELEX:52013SC0532\&from=EN 
Erisman, J. W., Galloway, J. N., Seitzinger, S., Bleeker, A., Dise, N. B., Petrescu, A. R., Leach, A. M., \& de Vries, W. (2013). Consequences of human modification of the global nitrogen cycle. Philosophical Transactions of the Royal Society B: Biological Sciences, 368: 20130116. https://doi.org/10.1098/rstb.2013.0116

Espósito, M. E., Blanco, M. D. C., Sequeira, M. E., Paoloni, J. D., Fernández, S. N., Amiotti, N. M., \& Díaz, S. L. (2016). Contaminación natural (As, F) y eutrofización (N, P) en la cuenca del arroyo El Divisorio, Argentina. Phyton - International Journal of Experimental Botany, 85, 51-62. ISSN: 00319457.

Fernández, P. L., \& Urricariet, S. (2014). Deterioro de los recursos naturales. Degradación y calidad de suelos. In P. B. Lombardo, P. L. Fernández \& S. Urricariet (Eds.), Agroecosistemas. Caracterización, implicancias ambientales y socioeconómicas, $1^{\mathrm{era}} \mathrm{ed}$, Buenos Aires, Argentina.

Finnveden, G., \& Potting, J. (1999). Eutrophication as an impact category. The International Journal of Life Cycle Assessment, 4: 311. https://doi.org/10.1007/BF02978518

Fowler, D., Coyle, M., Skiba, U., Sutton, M. A., Cape, J. N., Reis, S., .. \& Voss, M. (2013). The global nitrogen cycle in the twenty-first century. Philosophical transactions of the Royal Society of London. Series B, Biological Sciences, 368: 20130164.

Frischknecht, R., \& Jolliet, O. (2016). Global guidance for life cycle impact assessment indicators, 1.

Frischknecht, R., Jolliet, O., Berger, M., Fantke, P., Grant, T., Henderson, A. D., Owsianiak, M., \& Verones, F. (2019). Integration and Synthesis. In R. Frischknecht \& O. Jolliet (Eds.), Global Guidance on Environmental Life Cycle Impact Assessment Indicators, 2, pp 174-187.

Gallego, A., Rodríguez, L., Hospido, A., Moreira, M. T., \& Feijoo, G. (2011). Development of LCA characterization factors for terrestrial eutrophication at regional scale. Environmental Science \& Technology, 1: 21 .

Galloway, J. N. (2003). The global nitrogen cycle. TrGeo, 8, 682.

Galloway, J. N., Townsend, A. R., Erisman, J. W., Bekunda, M., Cai, Z., Freney, J. R., Martinelli, L. A., Seitzinger, S. P., \& Sutton, M. A. (2008). Transformation of the nitrogen cycle: recent trends, questions, and potential solutions. Science, 320: 889-892. https://doi.org/10.1126/science.1136674

Goedkoop, M., Heijungs, R., Huijbregts, M. A. J., De Schryver, A., Struijs, J., \& Van Zelm, R. (2013). $\mathrm{ReCiPe} 2008$. A life cycle impact assessment method which comprises harmonised category indicators at the midpoint and the endpoint level (1st ed. version 1.08). Report 1: Characterisation (No. 1st edition). VROM.

Goedkoop, M., Heijungs, R., Huijbregts, M. A. J., De Schryver, A., Struijs, J., \& Van Zelm, R. (2009). $\mathrm{ReCiPe} 2008$. A life cycle impact assessment method which comprises harmonised category indicators at the midpoint and the endpoint level, 1, 1-126.

Guinée, J. B., Gorrée, M., Heijungs, R., Huppes, G., Kleijn, R., de Koning, A., van Oers, L., Wegener Sleeswijk, A., Suh, S., Udo de Haes, H. A., de Bruijn, H., Van Duin, R., \& Huijbregts, M. A. J. (2002). Handbook on life cycle assessment: operational guide to the ISO standards. 
Hall, A. J., Rebella, C., Ghersa, C. M., \& Culot, J. P. (1992). Field-crop systems of the Pampas. In: C. J. Person (Ed.), Field Crop Ecosystems, Ecosystems of the World, Elsevier, Amsterdam.

Hassan, R., Scholes, R., \& Ash, N. (2005). Ecosystems and human well-being: current state and trends. Hauschild, M. Z., Goedkoop, M., Guinée, J., Heijungs, R., Huijbregts, M., Jolliet, O., ... \& Pant, R. (2013). Identifying best existing practice for characterization modeling in life cycle impact assessment. The International Journal of Life Cycle Assessment, 18: 683-697. https://doi.org/10.1007/s11367-012-0489-5

Hauschild, M. Z., Huijbregts, M., Jolliet, O., MacLeod, M., Margni, M., van de Meent, D., Rosenbaum, R. K., \& McKone, T. E. (2008). Building a model based on scientific consensus for life cycle impact assessment of chemicals: the search for harmony and parsimony. Environmental Science \& Technology, 42: 7032-7037. https://doi.org/10.1021/es703145t

Helmes, R. J. K., Huijbregts, M. A. J., Henderson, A. D., \& Jolliet, O. (2012). Spatially explicit fate factors of phosphorous emissions to freshwater at the global scale. The International Journal of Life Cycle Assessment, 17: 646-654. https://doi.org/10.1007/s11367-012-0382-2

Hellweg, S., \& Milà i Canals, L. (2014). Emerging approaches, challenges and opportunities in life cycle assessment. Science, 344: 1109-1113. 10.1126/ science.1248361

Henderson, A. D. (2015). Eutrophication. In M. Z. Hauschild \& M. A. J. Huijbregts (Eds.), Life Cycle Impact Assessment, pp 177-196.

Henryson, K., Hansson, P. A., \& Sundberg, C. (2017). Spatially differentiated midpoint indicator for marine eutrophication of waterborne emissions in Sweden. The International Journal of Life Cycle Assessment, 23: 70-81. https://doi.org/10.1007/s11367-017-1298-7

Hettelingh, J. P., Slootweg, J., \& Posch, M. (2004). Critical loads and dynamic modelling results, CCE Progress Report 2004. Working Group on Effects of the Convention on Long-range Transboundary Air Pollution. Netherlands.

Hilbert, J. A., \& Schein, L. (2018). Las huellas ambientales de la generación de valor. Buenos Aires, Argentina.

Huijbregts, M. A., Schöpp, W., Verkuijlen, E., Heijungs, R., \& Reijnders, L. (2000). Spatially explicit characterization of acidifying and eutrophying air pollution in life-cycle assessment. Journal of Industrial Ecology, 4: 75-92. https://doi.org/10.1162/108819800300106393

Huijbregts, M. A., Steinmann, Z. J., Elshout, P. M., Stam, G., Verones, F., Vieira, M., Zijp, M., Hollander, A., \& van Zelm, R. (2017). ReCiPe2016: a harmonised life cycle impact assessment method at midpoint and endpoint level. The International Journal of Life Cycle Assessment, 22: 138-147. https://doi.org/10.1007/s11367-016-1246-y

ISO. (2006a). ISO 14040: environmental management-life cycle assessment-principles and framework. Geneva, Switzerland.

ISO. (2006b). ISO 14044: environmental management-life cycle assessment-requirements and guidelines. Geneva, Switzerland. 
Jolliet, O., Antón, A., Boulay, A. M., Cherubini, F., Fantke, P., Levasseur, A., ... \& Frischknecht, R. (2018). Global guidance on environmental life cycle impact assessment indicators: impacts of climate change, fine particulate matter formation, water consumption and land use. The International Journal of Life Cycle Assessment, 23: 2189-2207. https://doi.org/10.1007/s11367-018-1443-y

Jolliet, O., Margni, M., Charles, R., Humbert, S., Payet, J., Rebitzer, G., \& Rosenbaum, R. (2003). IMPACT 2002+: a new life cycle impact assessment methodology. The International Journal of Life Cycle Assessment, 8: 324-330. https://doi.org/10.1007/BF02978505

Klöpffer, W. (2014). Introducing Life Cycle Assessment and its Presentation in 'LCA Compendium'. In: Klöpffer W (Ed.), Background and Future Prospects in Life Cycle Assessment. LCA Compendium-The Complete World of Life Cycle Assessment, Switzerland, pp 1-37.

Klöpffer, W. (1996). Reductionism versus expansionism in LCA. The International Journal of Life Cycle Assessment, 1: 61. https://doi.org/10.1007/BF02978643

Lavado, R. S. (2016). Degradación de los suelos argentinos. In F. X. Pereyra \& M. Torres Duggan (Eds.), Suelos y geología Argentina: una visión integradora desde diferentes campos disciplinarios (pp. 313328). Undav Ediciones, Asociación Argentina de la Ciencia del Suelo \& Asociación Geológica Argentina. ISBN 978-987-3896-10-1

Ledesma, C., Bonansea, M., Rodriguez, C. M., \& Delgado, A. R. S. (2013). Determinación de indicadores de eutrofización en el embalse Río Tercero, Córdoba (Argentina). Revista Ciência Agronômica, 44(3), 419-425. ISSN: 1806-6690

Li, Y., Schichtel, B. A., Walker, J. T., Schwede, D. B., Chen, X., Lehmann, C. M. B. Puchalski, M. A., Gay, D. A., \& Collett J. L. (2016). Increasing importance of deposition of reduced nitrogen in the United States. Proceedings of the National Academy of Sciences USA, 113: 5874- 5879.

Lindfors, L. G., Christiansen, K., Hoffman, L., Virtanen, Y., Juntilla, V., Hanssen, O. J., Rønning, A., \& Ekvall, T. (1995). Nordic guidelines on life-cycle assessment. Nordic Council of Ministers. ISBN: 929120-692X

Magrin, G. O., Travasso, M. I., \& Rodríguez, G. R. (2005). Changes in climate and crop production during the 20th century in Argentina. Climatic change, 72: 229-249. https://doi.org/10.1007/s10584-005-5374-9 Mariñelarena, A. J., \& Gómez, S. E. (2008). Eutrofización en las lagunas pampeanas. Biología Acuática, 24, 43-48. ISSN: 0326-1638

Martinelli, L. A., Howarth, R. W., Cuevas, E., Filoso, S., Austin, A. T., Donoso, L., ... \& Townsend, A. (2006). Sources of reactive nitrogen affecting ecosystems in in Latin America and the Caribbean: current trends and future perspectives. Nitrogen Cycling in the Americas: Natural and Anthropogenic Influences and Controls, 3-24.

Mengo, L., Lami, A., Guerra, L., Masuzzi, S., Piovano, E. L., \& Halac, S. R. (2019). Paleolimnología del embalse San Roque. Relación entre la eutrofización y la variabilidad hidroclimática. V Reunión Argentina de Geoquímica de la Superficie (RAGSU), 194-197. ISBN: 978-987-96296-7-3

Montenegro, C., Strada, M., Parmuchi, M. G., Bono, J., Stamati, M., Manghi, E., Brouver, M., Wabo, E., \& Bertolami, F. (2007). Informe sobre deforestación en Argentina 2007. Dirección de Bosques. Secretaria de Ambiente y Desarrollo Sustentable. Argentina. 
Morelli, B., Hawkins, T. R., Niblick, B., Henderson, A. D., Golden, H. E., Compton, J. E., Cooter, E. J., \& Bare, J. C. (2018). Critical Review of Eutrophication Models for Life Cycle Assessment. Environmental Science \& Technology, 52: 9562-9578. https://doi.org/10.1021/acs.est.8b00967

Mutel, C. L., Liao, X., Patouillard, L., Bare, J., Fantke, P., Frischknecht, R., ... \& Pfister, S. (2018). Overview and recommendations for regionalized life cycle impact assessment. The International Journal of Life Cycle Assessment, 24: 856-865. https://doi.org/10.1007/s11367-018-1539-4

Nilsson, L. O., Wallander, H., Bååth, E., \& Falkengren-Grerup, U. (2006). Soil N chemistry in oak forests along a nitrogen deposition gradient. Biogeochemistry, 80: 43-55.

Norris, G. A. (2008). Impact characterization in the tool for the reduction and assessment of chemical and other environmental impacts: Methods for acidification, eutrophication, and ozone formation. Journal of Industrial Ecology, 6: 79-101. https://doi.org/10.1162/108819802766269548

Núñez, M., Civit, B. M., Muñoz, P., Arena, A. P., Rieradevall, J., \& Antón, A. (2010). Assessing potential desertification environmental impact in life cycle assessment. The International Journal of Life Cycle Assessment, 15: 67-78. https://doi.org/10.1007/s11367-009-0126-0

Olivera, A., Cristobal, S., \& Saizar, C. (2016). Análisis de ciclo de vida ambiental, económico y social. Una herramienta para la evaluación de impactos y soporte para la toma de decisiones. Innotec gestión, 7:20-27.

ONU. (2018). La Agenda 2030 y los Objetivos de Desarrollo Sostenible: una oportunidad para América Latina y el Caribe. Objetivos, metas e indicadores mundiales.

Paerl, H. W., \& Scott, J. T. (2010). Throwing fuel on the fire: synergistic effects of excessive nitrogen inputs and global warming on harmful algal blooms. Environmental Science \& Technology, 44: 77567758. https://doi.org/10.1021/es102665e

Pardo, L. H., Fenn, M. E., Goodale, C. L., Geiser, L. H., Driscoll, C. T., Allen, E. B., ... \& Dennis, R. L. (2011). Effects of nitrogen deposition and empirical nitrogen critical loads for ecoregions of the United States. Ecological Applications, 21: 3049-3082.

Paruelo, J. M., Guerschman, J. P., \& Verón, S. R. (2005). Expansión agrícola y cambios en el uso del suelo. Revista Ciencia Hoy, 15: 14-23.

Payen, S., Civit, B. M., Golden, H., Niblick, B., Ubizeye, A., Winter, L., \& Henderson, A. D. (2019). Acidification \& Eutrophication. In Frischknecht R, Jolliet O (Eds.), Global Guidance on Environmental Life Cycle Impact Assessment Indicators, 2, pp 60-79.

Pereyra, F. X. (2012). Suelos de la Argentina. Geografía de suelos, factores y procesos formadores. SEGEMAR, GAEA y AACS, Anales del SEGEMAR 50.

Perez, G. A. (2016). Antecedentes. In P. Garolera De Nucci, F. D. Mele, A. L. Nishihara Hun \& G. A. Perez (Eds.), Avances y estado de situación en análisis de ciclo de vida y huellas ambientales en la Argentina: Actas del V Encuentro Argentino de Ciclo de Vida y IV Encuentro de la Red Argentina de Huella Hídrica ENARCIV 2016 (1era ed., pp. 6-7). Ediciones INTA. ISBN: 978-987-521-810-9 
Perring, M. P., Bernhardt-Römermann, M., Baeten, L., Midolo, G., Blondeel, H., Depauw, L., ... \& Verheyen, K. (2018). Global environmental change effects on plant community composition trajectories depend upon management legacies. Global Change Biology, 24(4), 1722-1740. https://doi.org/10.1111/gcb.14030

Pilkington, M. G., Caporn, S. J. M., Carroll, J. A., Cresswell, N., Lee, J. A., Ashenden, T. W., Brittain, S. A., ... \& Emmett, B. A. (2005). Effects of increased deposition of atmospheric nitrogen on an upland moor: Leaching of N species and soil solution chemistry. Environmental Pollution, 135: 29-40.

Posch, M., Seppälä, J., Hettelingh, J. P., Johansson, M., Margni, M., \& Jolliet, O. (2008). The role of atmospheric dispersion models and ecosystem sensitivity in the determination of characterisation factors for acidifying and eutrophying emissions in LCIA. The International Journal of Life Cycle Assessment, 13: 477-486. https://doi.org/10.1007/s11367-008-0025-9

Potting, J., \& Hauschild, M. Z. (2006) Spatial differentiation in life cycle impact assessment: a decade of method development to increase the environmental realism of LCIA. The International Journal of Life Cycle Assessment, 11: 11-13. https://doi.org/10.1065/lca2006.04.005

Potting, J., \& Hauschild, M. Z. (2005). Background for spatial differentiation in LCA impact assessmentThe EDIP2003 methodology. Danish Ministry of the Environment, Environmental Project, 996: 293. Denmark.

Potting, J., \& Hauschild, M. Z. (2004). Background for spatial differentiation in life cycle impact assessment. The EDIP2003 methodology. Denmark.

Potting, J., \& Hauschild, M. Z. (1997). Predicted environmental impact and expected occurrence of actual environmental impact. Part II: Spatial differentiation in life cycle assessment via the site-dependent characterisation of environmental impact from emissions. The International Journal of Life Cycle Assessment, 2: 209-216.

Potting, J., Klöpffer, W., Seppälä, J., Risbey, J., Meilinguer, S., Norris, G., Lindfords, G. L., \& Goedkoop, M. (2001). Best available practice in life cycle assessment of climate change, stratospheric ozone depletion, photo-oxidant formation, acidification and eutrophication. Backgrounds and general issues.

Quirós, R. (2000). La eutrofización de las aguas continentales de Argentina. In A. Fernández (Ed.), El Agua en Iberoamérica: acuíferos, lagos y embalses (pp. 43-47). CYTED. Subprograma XVII. Aprovechamientos y gestión de recursos hídricos.

Rosenbaum, R. K., Hauschild, M. Z., Boulay, A. M., Fantke, P., Laurent, A., Núñez, M., \& Vieira, M. (2018). Life cycle impact assessment. In Hauschild M, Rosenbaum R, Olsen S (Eds.), Life Cycle Assessment.

Rubio, G., Lavado, R. S., \& Pereyra, F. X. (2019). The Soils of Argentina.

Schmid, A. G. (2008). Diferenciación espacial en la metodología de Análisis del Ciclo de Vida: desarrollo de factores regionales para eutrofización acuática y terrestre. Santiago de Compostela, España. ISBN: 13: $978-84-612-8888-5$

Seppälä, J., Posch, M., Johansson, M., \& Hettelingh, J. P. (2006). Country-dependent characterisation factors for acidification and terrestrial eutrophication based on accumulated exceedance as an impact 
category indicator. The International Journal of Life Cycle Assessment, 11: 403-416. https://doi.org/10.1065/lca2005.06.215

Seppälä, J., Risbey, J., Meilinger, S., Norris, G., Lindfors, G. L., \& Goedkoop, M. (2001). Best available practice in life cycle assessment of climate change, stratospheric ozone depletion, photo-oxidant formation, acidification, and eutrophication-Backgrounds on general issues. RIVM.

Simkin, S.M., Allen, E. B., Bowman, W. D., Clark, C. M., Belnap, J., Brooks, M. L., ... \& Cade, B. S. (2016). Conditional vulnerability of plant diversity to atmospheric nitrogen deposition across the USA. Proceedings of the National Academy of Sciences of the United States of America, 113: 4086-4091.

Stevens, C. J., Dise, N. B., Gowing, D. J. G., \& Mountford, J. O. (2006). Loss of forb diversity in relation to nitrogen deposition in the UK: Regional trends and potential controls. Global Change Biology, 12: 1823-1833.

Töpfer, K. (2002). The Launch of the UNEP-SETAC Life Cycle Initiative. Editorial. The International Journal of Life Cycle Assessment, 7: 191.

UBA. (1996). Manual and methodologies and criteria for mapping critical levels/loads and geographical areas where they are exceeded. Texte 71/96. UN/ECE convention on long-range transboundary air pollution. Federal Environmental Agency. Germany.

Vellend, M., Baeten, L., Becker-Scarpitta, A., Boucher-Lalonde, V., McCune, J. L, Messier. J., ... \& Sax, D. F. (2017). Plant biodiversity change across scales during the Anthropocene. Annual Review of Plant Biology, 68, 563-586. https://doi.org/10.1146/annurev-arplant-042916-040949

Verones, F., Hellweg, S., Azevedo, L. B., Chaudhary, A., Cosme, N., Fantke, P., ... \& Huijbregts, M. A. J. (2016). LC-Impact Version 0.5. A spatially differentiated life cycle impact assessment approach.

Verones, F., Liao, X., de Souza, D. M., Fantke, P., Henderson, A. D., Posthuma, L., \& Laurent, A. (2019). Crosscutting Issues. In Frischknecht R, Jolliet O (Eds.), Global Guidance on Environmental Life Cycle Impact Assessment Indicators, 2, pp 42-59.

Vestreng, V., Goodwin, J., \& Adams, M. (2004). Inventory Review 2004. Emission data reported to CLRTAP and under the NEC Directive. EMEP/EEA Joint Review Report. Norwegian. 